\title{
PARENTS' PERCEPTIONS OF FOOD ADVERTISING AIMED AT CHILDREN ON TELEVISION: EXPOSURE, INFLUENCE AND REGULATIONS
}

\begin{abstract}
SUMMARY
The purpose of this work is to investigate the perceptions of parents about advertising of food to children on television. The theoretical research includes a review of marketing to children, the analysis of influential factors, the influence of food advertising aimed at children, the perceptions of the parents and the issue of regulation of this area of advertising. The empirical research conducted via a questionnaire to the parents does not confirm the connection between the time spent in front of the television and the behaviour of children, but it does indicate at the negative attitudes of parents about advertising of food that influence their moderately restrictive attitude on the prohibition of such advertising.
\end{abstract}

Key Words: advertising to children, television advertising, perceptions of parents, regulation, Croatia

\section{INTRODUCTION}

Marketing activities wield a powerful influence on customers' behaviour and children are increasingly becoming a focus of their attention. A growing concern about the potentially damaging effects of food advertising to children, which is still mostly done via television advertising, regardless of the appearance of new media, has been present in the world for several years. Bearing in mind the multiple effects that the watching of television and food advertising have on children's knowledge about nutrition, their preferences and their behaviour, warnings about their negative influence on nutrition and health of children have recently become stronger. Since parents are responsible for the nutrition of their children and are an important factor in the children's choice of food the purpose of his work was to research the attitudes of the parents about food adverts to children on television in Croatia.

For this purpose, a theoretical framework providing the factors that influence the choice of food in children and their interaction, and a short review of the present marketing activities aimed at children in relation to food are given in the first part of the work. The key problem of advertising of food to children is the type of food that is advertised, which coupled with the creative force of persuasion and the frequency of advertising of specific food i.e. the percentage of advertising of unhealthy foods in the overall programme with respect to the frequency of viewing of the programme by the child, among other things, influences the final effect of the media. Findings of numerous researches about television advertising of food to children, most of which were carried out in the USA, are provided in the following chapter. Next is the consideration of parents' perceptions about advertising of food to children, which

\footnotetext{
${ }^{1}$ Ph.D., Juraj Dobrila University of Pula, Department of Economics and Tourism - Dr. M. Mirković, Pula, Preradovićeva1/1, astok@efpu.hr

${ }^{2}$ M.Sc., Juraj Dobrila University of Pula, Department of Economics and Tourism - Dr. M. Mirković, Pula, Preradovićeva 1/1,
} 
are very important in the definition of the legislative regulations whose options for the solution of the researched issue are examined in the last theoretical chapter. The aim of the empirical research is to shed light on this problem in Croatian settings.

\section{THE ROLE OF MARKETING OF FOOD TO CHILDREN IN THE SELECTION OF FOODS AND ACQUIRING OF NUTRITIONAL HABITS IN CHILDREN}

The purpose of food is to satisfy basic human needs. It gets constantly and repeatedly consumed and it is, at the same time, present on a very competitive market and therefore significant efforts and funds are invested into its marketing and into building of brands. According to the data, in 2007, food was the third most advertised category in Croatia with $10.8 \%$ (Lider, www-liderpress.hr). Children are an attractive market segment for marketers because the habits of consuming of a product acquired in childhood and preferences towards specific brands significantly influence consuming at an adult age.

A series of mutually interactive factors influence children's choice of foods: (Livingstone, Helsper, 2004)

1. Individual factors (psychosocial, biological and behavioural factors)

2. Social environment (family, friends)

3. Community (schools and facilities such as fast food restaurants, vending machines, shops and workplace restaurants)

4. Macrosystem (consumerism, production and distribution systems, pricing policies, mass media and advertising: media saturated environment, advertising foods to children, exposure to television, effects on demands for food, influence on perception of one's body).

Children are exposed to advertising from a very early age by visiting shops with parents, where the package is an important factor of impulsive shopping by children (Hill, 2002). They also often encounter advertising in schools through vending machines, direct advertising in schools, indirect advertising e.g. in school manuals or through various marketing researches (Kirstin, 2002). From all the daily encounters with the media, television is the most important source of messages from the media about food aimed at children. An average British child spends about 17 hours a week in front of a television and views an average of 28 advertisements per day, of which an average of $71 \%$ is beyond the children's programme time-slot (Ofcom, 2004). Along with a prolonged sedentary lifestyle, consuming of high-calorie foods with meagre nutritional values contributes significantly to an increased body weight in children (Caroli, Argentieri, Cardone, Masi, 2004) with the consequent risk of related illnesses and, sometimes, the stigmatising of the community (Schwartz, Puhl, 2003). Since a growing number of children have Internet access the marketers integrate advertising on the web in many different ways (f.eg. games, puzzles, quizzes, music, screensavers etc.), while some of the companies even use phone texting for their adverts (Corbett, Walker, 2009). A common marketing approach is also represented by many promotions such as crossselling and tie-in. The marketers also use other available possibilities in order to reach children. In order to create an early positive relationship between the child and the brand the food producers increasingly use toys or picture books featuring the company trademark, while children's clubs, which are well accepted by children, enable mass marketing on a personalised level. It is becoming increasingly popular to feature a product in entertainment media, most frequently in films, but also in books, comics, songs etc., creating familiarity and brand preference in a sophisticated manner (Story, French, 2004). 


\section{CONTENT OF ADVERTISING TO CHILDREN}

Food is amply represented in television adverts aimed at children. So, Lee and Tseng (2006) have determined that the frequency of advertising of food in the total number of television adverts for children on television in the USA is equal to 31.5\% (Lee, Tseng, 2006), according to the research of Wilson, Quigley and Mansoor (1999) in New Zealand it equals $29 \%$, in Australia Zuppa, Morton and Mehta (2003) have found that food advertising participates with 32\% while Roberts and Pettigrew (2007) mention 22.3\%.

What is particularly worrying is the type of food advertised to children. According to the research of Roberts and Pettigrew (2007) the participation of food with a high fat content and sugar is $72.2 \%$ and if advertising for fast food restaurants is included it rises to $79 \%$ according to the research by Zuppa, Morton and Mehta (2003). According to the last authors, when compared with recommendations for healthy nutrition of children under 11 years of age the advertised food is a complete opposite to the recommended food (Zuppa, Morton, Mehta, 2003). Similarly, according to a research of Wilson, Quigley and Mansoor (1999) the participation of such food in advertising is $63 \%$. By a nutritional analysis it was further established that should one consume exclusively food advertised on television, this would lead to an excessive intake of energy from fats in the food, an excessive intake of saturated fats, proteins, sugars and salt, with a deficiency in fibres and many other important substances such as magnesium, selenium and vitamin E (Wilson, Quigley and Mansoor, 1999). Moreover, the research of Lee and Tseng (2006) has established that the food which was advertised to children contains and excessive amount of fat in $18.8 \%$ of the cases, $6.3 \%$ of salt, $1.6 \%$ of cholesterol and in as many as $82.2 \%$ of the cases an excessive quantity of sugar. It is indicative that such, generally, low quality food is advertised in an attractive and seductive way, and so Roberts and Pettigrew (2007) have found out that the appeals most used were the following: fantasy (17\%), humour (13\%) taste $(12 \%)$ and action and adventure $(11 \%)$, with a strong use of various rewards. Contrary to the food's actual nutritional value Lee and Tseng (2006) find that advertising of such food in $31.6 \%$ of the cases emphasises the taste and the aroma, in $28.1 \%$ it advertises its "cool" appeal and in $10.5 \%$ of the cases it emphasises its shape or colour.

Advertising of food to children in the printed media, according to the findings of Mendzigall and Morrison (2008), also abounds in food that has a high fat, oil and sugar content $(58.3 \%)$ and there is no advertising for fruits and vegetables. Since children have increasingly been using the Internet the marketers have found new ways to attract them in advergames, i.e. on-line games that contain brand identifiers. In the US $63 \%$ of food and beverages manufacturers have included such games on their web sites (Lee, Choi, Quilliam, Cole, 2009). Contrary to the passive viewing of television learning about brands is amplified by active participation, a pleasant experience and fun during the game.

\section{INFLUENCE OF TELEVISION FOOD ADVERTISING ON CHILDREN}

Among the many mentioned factors that influence the nutritional habits of children food advertising contributes independently with $2 \%$ of explained variation, which is consistent with the findings on the effects of media in other areas. (Livingstone, Helsper, 2004) Advertising of food, primarily via television, has a multiple influence. On the child's cognitive and emotional level advertising becomes the source of knowledge about the product and the brand, it influences the knowledge, opinions and values about the product and the brand and, on a wider scale, it influences social interaction in consumption. The final goal of advertising is the achievement of specific behaviour i.e. the purchase of a specific brand, where children, especially the really young ones that have no personal financial means, often 
pester their parents, possibly resulting in a family conflict (Gunter, Oates, Blades, 2005). On the basis of numerous researches in the last 40 years that have involved children of different age groups there is a general consensus that advertising aimed at children via television has a mild direct effect on knowledge about food, food preferences and the children's behaviour related to food (Livingstone, 2005). There is also modest evidence of the effect on knowledge about food, strong evidence of the effect on food preferences and behaviour that is related to shopping i.e. the effect on parents, and it has been found that promotion of food may, depending on the circumstances, induce single or short-term consumption and consumption patterns in children (Hastings, 2003). In addition to this direct effect of advertising on children, the indirect effects that may be important need to be taken into account such as lifestyle changes, changes in habits, cultural expectations and especially values and behaviour of peers in whose company it may be e.g. desirable to consume a certain product (Livingstone, 2004). Contrary to the general belief, the results of the researches on the influence of food advertising to children are clearer for older children while the opposite is true for the youngest age group (up to 6 years of age), which does not mean that this age group is less vulnerable but that other reasons, such as e.g. a lesser dedication to media, research methods and other reasons may have influenced the results of the research (Livingstone, Helsper, 2004).

The newest researches, mostly after the year 2000, more significantly target the effects of marketing and advertising on children's health and obesity. Among many other influences on child obesity (Ofcom, 2004), watching of television is continuously mentioned as a key factor. The reason for this is because watching TELEVISION is: (Ofcom, 2004) (1) a sedentary activity that slows the metabolism and replaces physical exercise (2) connected to snacks, fast food and fast food consumption during viewing (3) includes exposure to advertising of "unhealthy" products. Even though there is an important relation between watching of television and advertising of food on television and the children's nutrition routine, and even though it does not cause, but certainly contributes to obesity (Harker, Burns), there is no sufficient evidence of their single relative influence in relation to other factors (Hastings et al., 2003). While children demand foods which is mostly rich in sugar, salt and fat as a consequence of advertising of such foods on television, (Arnas, 2006), advertising of "healthy" food and positive messages from the public health care service may bring positive results with respect to health and obesity in children (Lobstein, Dibb, 2005).

\section{PARENTS’ PERCEPTIONS ON ADVERTISING OF FOOD AIMED AT CHILDREN}

Parents play an important role in the choice of food, the nutritional habits and the health of their children, depending on their financial situation and education, employment status, habits involving meals and mealtime, availability of food in their home and their convictions regarding nutrition. Their influence is, however, especially with older children, strongly interdependent with the influence of the children's peers and the media, having a "bounce back" effect on food consumption in the household, even in those families that tend to eat healthy food (Kelly, Turner, McKenna, 2006). Due to the limited ability of a child to understand advertising (Gunter, Oates, Blades, 2005) parents often express their concern with respect to advertising of food aimed at children on television and usually they can, depending on their communication patterns with their children and their attitude towards advertising (Grossbart, Crosby, 1984) intervene on the effect of advertising on children, e.g. by limiting viewing time or by watching television with their children and by discussing what is being broadcasted, thereby contributing to the children's media literacy and their adoption of other social norms (Livingstone, Helsper, 2004). According to Ofcom's research it appears, 
however, that in Great Britain (2004) as many as $44 \%$ of the parents never discuss advertising on television with their children, $4 \%$ discuss it very often and $1 \%$ of the parents discuss it all the time, while the others do it sometimes, seldom or very rarely. Since the socialization of children is a two-way process, watching television stimulates children to ask for advertised foods, especially if they watch television while having their regular meals, which can lead to the annoyance of parents or even a family conflict either at home or at the shop (Livingstone, Helsper, 2004). The greater is the conviction of parents that their children are influenced by advertising, the greater will be the feeling that such a situation leads to conflict and the greater will be the parents' control over children's watching of television (Dens, De Pelsmacker, Eagle, 2007). It may become very difficult for the parents to prohibit the purchase of a product that is advertised by a favourite animated film character or a celebrity (Kelly, Turner, McKenna, 2006).

According to the research of Young, de Bruin and Eagle (2003) about the opinion of the parents about advertising aimed at children in Great Britain, Sweden and New Zealand, there is an agreement in all the three cultures that advertising to children is excessively disproportionate and that it leads children to pester parents to buy a specific product, and that, irrespectively of their material status, parents equally tend to give in to such pressure. (Ban, 2009) While advertising of foods to children on television is not considered to be an important factor/cause of unhealthy eating habits in New Zealand (average value of 3.5 in the range 1-5), nor it is considered to be the main influence on the nutrition of children in Great Britain (average value of 2.39 in the range 1-5) or Sweden (average value 1.52 in the range 15 ), there is a greater concern for the excessive content of sugars, fats and additives (average value of 4.0 in the range 1-5) in New Zealand parents. The research of Ip, Mehta and Coveney (2007) of a focus group has also found the existence of a negative and critical attitude towards advertising of foods has revealed concerns about the manipulation of children because of their naiveté. Some parents question the truthfulness of the advertising messages and protest to the employment of celebrities in the promotion of unhealthy foods. Research in the USA generally finds clearly negative attitudes of parents towards advertising of food to children, e.g. Spungin (2004) finds that even though the largest percentage of the believe that advertising is a commercial reality (45\%), negative attitudes are prevalent, where $12 \%$ of the parents believe that advertising to children should be banned, $27 \%$ of the parents do not like it but do not think it should be banned and $15 \%$ of the parents have a positive attitude towards advertising to children. Conversely, according to the research of Dens, De Pelsmacker and Eagle (2007), parents in Belgium are not too concerned about the influence of advertising on children, especially about the advertising of food to children. This divergence in the findings may be explained e.g. by the media environment, characteristics of the parents or the group of children that was researched.

The perceived influence of advertising on children and the attitudes towards advertising of food are, according to the research of Dens, De Pelsmacker and Eagle (2007), the most important factor in the desire of the parents to regulate this area in legislation. According to a research of Ofcom (2004), 56\% of the parents in Great Britain believe that changes are necessary in the laws regulating the advertising of food to children. While a smaller number of parents (24\%) supports the prohibition of advertising, others want advertising that will be more informative, meaning that it should contain nutritional information about the foods $(81 \%)$ and that it should exclude the claim that a product is healthy if, for some reason, it is not (65\%), adverts should be less appealing to children $(65 \%)$, animated characters $(49 \%)$ as well as celebrities $(48 \%)$ should be prohibited from appearing in advertising of unhealthy foods to children. Also, $57 \%$ of the parents are inclined to a prohibition of advertising of unhealthy foods during the broadcast of children's programmes and 48\% have declared that such products should not be advertised before 21:00 
hours. However, as Walsh, Laczniak and Carlson (1998) have found, one should consider the fact that preferences of mothers about the regulation of advertising on television may differ depending on the parenting style in the socialization of the child.

\section{A REVIEW OF THE ISSUE OF LEGISLATIVE REGULATION OF FOOD ADVERTISING TO CHILDREN}

The issue of protection of children from television advertising ensues from the following areas of concern by consumers' organizations: (Gunter, Oates, Blades, 2005) (1) quantity of advertising aimed at children, (2) types of advertising that prevail in children's programmes (3) marketing techniques that are used to attract children, (4) lack of sufficient application of regulations on advertising, (5) the influence exerted by transferring of the content of an advertisement from one country to another and circumventing of the regulations of the receptive country. Since 2004, when the World Health Organization invited the governments, the industry and the civilised society to decrease the number of unhealthy food adverts, Hawkes found out that the greatest progress around the world until 2006 was achieved in the area of self-regulation, while the actual legislative regulations that refer to advertising of food to children, including the restrictive approaches, developed very slowly (Hawkes, 2007).

The approaches that may be used to change the relation between the media and the choice of foods in children are: (Livingstone, Helsper, 2004) (1) prohibition of any kind of advertising for small children, (2) prohibition of unhealthy food advertising for small children, (3) prohibition of the introduction of products in children's programmes, (4) ensuring that even broadcast time is given to messages about nutrition or exercise in order to counteract food advertisements, (5) issuing of "warnings" to parents about the nutritional value of the advertised food, (6) revoking of tax alleviations for companies that are related to unhealthy food advertising, (7) prohibition of advertising or promoting of food in schools, (8) providing of explicit information about the contents related to food in popular programmes seen by children, (9) prohibition or limiting of cross-selling between characters popular with children in the media or celebrities and unhealthy food, 10) an increased use of popular media characters or celebrities in the promotion of healthy food, (11) better labelling and better information about healthy and unhealthy food. Even though some countries have adopted the prohibition of advertising to children such as Sweden and Quebec (Ofcom, 2004), and many others introduce various restrictions, like Great Britain that in 2007 prohibited advertising of unhealthy food during the broadcasting of programmes for children under the age of 16 (Darwin, 2009), a serious, wide intervention in this area is still uncertain because of the supremacy of commercial interests over the health of children.

\section{RESEARCH OF THE PARENTS' PERCEPTION OF ADVERTISING OF FOOD TO CHILDREN 7.1. METHODOLOGY OF RESEARCH}

First of all, the research wished to determine the number of food advertisements that the children are actually exposed to on Croatian television channels. When selecting the time of tracking of the advertising Ofcom data were used about the children's television ratings in the age between 10 and 15 in Great Britain (Ofcom, 2004) which were corrected for the children's programme timeslot on Croatian television channels. A total of 40 hours of programme was followed during September and October 2010, according to the programme of the following channels: HRT1, HRT2, RTL, NOVA TELEVISION from 7 to 8 am and in the afternoon on HRT1 from 20 to 22 pm, HRT2 from 18 to 20 pm, RTL from 16 to 18 pm, 
NOVA TELEVISION from 20 to $22 \mathrm{pm}$, and Saturdays and Sundays all programmes in the morning from 8 to 10 am and in the afternoons at the same time as weekdays.

The research of the attitudes of the parents about advertising to children was carried out in two elementary schools in Rovinj, the ES Jurja Dobrile and the ES Vladimir Nazor, and in the ES Vladimir Gortan in Žminj. A total group of parents of 262 children attending the $5^{\text {th }}$ and $6^{\text {th }}$ grade of elementary school, i.e. parents of 221 pupils in Rovinj and parents of 41 pupils in Žminj were examined. The questionnaire was filled in on a parent information meeting by one of the children's parents. Out of 202 questionnaires $(77 \%$ of the total number of questioned parents) which were filled in by an appropriate sample of parents on parent information meetings 25 were incorrectly filled in, while 10 questionnaires were excluded due to the presence of outliers (values greater of $+/-3$ standard deviation, which can influence the calculation of the correlations and average values). The final interpretation of the results of the research is based on 167 questionnaires (63\% of the total number of parents participating). The questionnaire, in addition to the question about the time that the children spend in front of the television, contains 14 statements with a Likert 5-degree scale.

The work starts from the supposition that opinions on advertising of food, knowledge, behaviour, conflict in the family and nutritional habits of children influence the attitudes of the parents about the legislative regulation of advertising to children. Consequently, the following hypotheses are made:

H1: Time spent in front of the television is related to the perceptions of the parent about the children's knowledge, behaviour and the conflicts related to food

H2: The perceptions of the parents about advertising of food to children influence the attitudes of the parents about the legislative regulation of advertising of food to children on television

H3: The perceptions of the parents about the knowledge, behaviour, conflict and nutritional habits of children in relation to the advertised food influence the attitudes of the parents about the legislative regulation of advertising of food to children on television 


\subsection{RESULTS OF THE RESEARCH}

\subsubsection{ANALYSIS OF THE INCIDENCE OF FOOD ADVERTISING AIMED AT CHILDREN}

Tracking of the programme in the mentioned day periods produced the results provided in Table 1.

Table 1

\section{Total number of adverts on television, adverts to children and children's food adverts}

\begin{tabular}{|c|c|c|c|c|c|c|c|c|c|c|}
\hline \multirow[b]{2}{*}{ Channel } & \multirow[b]{2}{*}{ Day } & \multicolumn{4}{|c|}{ Morning } & \multicolumn{4}{|c|}{ Afternoon and Evening } & \multirow[b]{2}{*}{$\begin{array}{c}\text { Warning } \\
\text { about } \\
\text { oncoming } \\
\text { advertising }\end{array}$} \\
\hline & & $\begin{array}{c}\text { Total } \\
\text { number } \\
\text { of } \\
\text { adverts }\end{array}$ & $\begin{array}{l}\text { Adverts } \\
\text { to } \\
\text { children }\end{array}$ & $\begin{array}{l}\text { Children's } \\
\text { food } \\
\text { adverts }\end{array}$ & $\begin{array}{l}\text { Percentage } \\
\text { of } \\
\text { children's } \\
\text { food in the } \\
\text { total } \\
\text { number of } \\
\text { adverts } \\
\end{array}$ & $\begin{array}{l}\text { Total } \\
\text { number } \\
\text { of } \\
\text { adverts }\end{array}$ & $\begin{array}{l}\text { Adverts } \\
\text { to } \\
\text { children }\end{array}$ & $\begin{array}{l}\text { Children's } \\
\text { food } \\
\text { adverts }\end{array}$ & $\begin{array}{c}\text { Percentage } \\
\text { of } \\
\text { children's } \\
\text { food in the } \\
\text { total } \\
\text { number of } \\
\text { adverts }\end{array}$ & \\
\hline \multirow{3}{*}{ HRT1 } & $\begin{array}{c}\text { work } \\
\text { day }\end{array}$ & 3 & - & - & - & 20 & 1 & - & - & \multirow{3}{*}{ Not always } \\
\hline & Saturday & 6 & - & - & - & 22 & 1 & 1 & $5 \%$ & \\
\hline & Sunday & 5 & 4 & 1 & $20 \%$ & 39 & 1 & 1 & $3 \%$ & \\
\hline \multirow{3}{*}{ HRT2 } & $\begin{array}{c}\text { work } \\
\text { day }\end{array}$ & 4 & 1 & - & - & 10 & 1 & 1 & $10 \%$ & \multirow{3}{*}{ Yes } \\
\hline & Saturday & 7 & 7 & 1 & $14 \%$ & 3 & - & - & - & \\
\hline & Sunday & 3 & - & - & - & 9 & 1 & 1 & $11 \%$ & \\
\hline \multirow{3}{*}{ RTL } & $\begin{array}{c}\text { work } \\
\text { day }\end{array}$ & 13 & 7 & 6 & $46 \%$ & 28 & 3 & 2 & $7 \%$ & \multirow{3}{*}{ Not always } \\
\hline & Saturday & 52 & 2 & 1 & $2 \%$ & 56 & 14 & 4 & $29 \%$ & \\
\hline & Sunday & 24 & 12 & 12 & $50 \%$ & 62 & 1 & - & - & \\
\hline \multirow{3}{*}{$\begin{array}{c}\text { NOVA } \\
\text { TELEVISION }\end{array}$} & $\begin{array}{c}\begin{array}{c}\text { work } \\
\text { day }\end{array} \\
\end{array}$ & 17 & 13 & 8 & $47 \%$ & 44 & 3 & 3 & $7 \%$ & \multirow{3}{*}{ Yes } \\
\hline & Saturday & 48 & 36 & 7 & $15 \%$ & 51 & 1 & 1 & $2 \%$ & \\
\hline & Sunday & 63 & 51 & 4 & $6 \%$ & 44 & 3 & 3 & $7 \%$ & \\
\hline
\end{tabular}

Source: Authors

The tracking of adverts showed that children's food adverts are moderately present (they represent a share of $9 \%$ in the total number of adverts and 35\% in adverts to children) and none of the channels broadcast warnings about the oncoming advertising which is unethical. Also, it has been noticed that children appear in adverts that are not intended for children and that do not refer to products for children, which suggests at the power of adverts that use the appeal of children. 


\subsubsection{PARENT QUESTIONNAIRE RESULTS}

Table 2 presents mean values of the attitudes of parents, while table 3 presents the results of the correlation analysis. No statistically significant relation has been found between the hours spent in front of the television (an average of $2.5 \mathrm{hrs}$ ) and the attitudes of the parents. By examining of the mean values it can be noticed that parents believe their children are exposed to an ample amount of food adverts (mean value 3.87) which is, according to the values in table 2, still less than in countries that are economically better developed than Croatia. Also, they believe that the advertised products contain too much sugar and fat and that they contain too many additives (mean value 4.10).

Table 2

Descriptive analysis of the attitudes of the parents

\begin{tabular}{|c|c|c|c|c|}
\hline Item & Statements & $\mathbf{N}$ & Mean & $\begin{array}{l}\text { Std. } \\
\text { Dev } \\
\text { iati } \\
\text { on }\end{array}$ \\
\hline T1 & Children are exposed to too many food adverts on television & 167 & 3.87 & .93 \\
\hline $\mathbf{T} 2$ & $\begin{array}{l}\text { The food that is advertised on television to children contains too } \\
\text { much sugar and fat }\end{array}$ & 167 & 4.10 & $\begin{array}{l}.77 \\
8\end{array}$ \\
\hline T3 & $\begin{array}{l}\text { The food that is advertised on television to children contains too } \\
\text { many additives }\end{array}$ & 167 & 4.10 & $\begin{array}{l}.80 \\
1\end{array}$ \\
\hline T4 & $\begin{array}{l}\text { The food that is advertised on television to children improves } \\
\text { children's knowledge about a healthy nutrition }\end{array}$ & 167 & 2.60 & $\begin{array}{l}1.1 \\
72\end{array}$ \\
\hline T5 & $\begin{array}{l}\text { Children ask the parents to purchase food that is advertised on } \\
\text { television }\end{array}$ & 167 & 3.75 & $\begin{array}{l}1.0 \\
67\end{array}$ \\
\hline T6 & $\begin{array}{l}\text { The food that is advertised on television is the reason for which } \\
\text { children pester their parents to purchase such food }\end{array}$ & 167 & 3.66 & $\begin{array}{l}1.1 \\
07\end{array}$ \\
\hline T7 & $\begin{array}{l}\text { The food that is advertised on television is the cause of family } \\
\text { conflicts in relation to nutrition }\end{array}$ & 167 & 3.00 & $\begin{array}{l}1.1 \\
41\end{array}$ \\
\hline T8 & $\begin{array}{l}\text { The food that is advertised on television is a significant cause of } \\
\text { unhealthy nutritional habits in children }\end{array}$ & 167 & 3.71 & $\begin{array}{l}1.0 \\
55\end{array}$ \\
\hline T9 & Advertising of all unhealthy foods should be prohibited & 167 & 3.96 & $\begin{array}{l}.99 \\
9\end{array}$ \\
\hline T10 & $\begin{array}{l}\text { Advertising of unhealthy foods to children under } 12 \text { years of } \\
\text { age should be prohibited } \\
\text { Television should broadcast programmes about healthy nutrition }\end{array}$ & 167 & 3.99 & .99 \\
\hline T11 & $\begin{array}{l}\text { and exercising for at least as much broadcast time it provides } \\
\text { for unhealthy foods advertising }\end{array}$ & 167 & 4.57 & $\begin{array}{l}.66 \\
3\end{array}$ \\
\hline T12 & $\begin{array}{l}\text { When advertising unhealthy food its nutritional value should be } \\
\text { presented }\end{array}$ & 167 & 4.16 & $\begin{array}{l}.82 \\
1\end{array}$ \\
\hline T13 & $\begin{array}{l}\text { When advertising foods with a high content of sugar and fat } \\
\text { animated characters and celebrities should not be used }\end{array}$ & 167 & 4.18 & $\begin{array}{l}.84 \\
5\end{array}$ \\
\hline T14 & $\begin{array}{l}\text { It is desirable to use animated characters and celebrities to } \\
\text { promote healthy foods }\end{array}$ & 167 & 4.12 & $\begin{array}{l}.98 \\
1\end{array}$ \\
\hline & HOURS_TELEVISION & 167 & & $\begin{array}{l}.97 \\
6\end{array}$ \\
\hline
\end{tabular}

Source: Authors' calculation 
Food adverts to children, according to the opinion of the parents, do not increase the children's knowledge about healthy nutrition (mean value 2.60), but are, on the contrary, the cause of their unhealthy eating habits (mean value 3.71). This is preceded by their request that advertised food be purchased (mean value 3.75), and pestering of parents (mean value 3.66) which however does not cause family conflicts (mean value 3.00). The results of the correlation analysis in table 3 do not confirm the relation between the time spent in front of the television and the attitudes of parents towards the advertised food, which does not confirm $\mathrm{H} 1$, but confirms a significant relation $(\mathrm{p}<0.05)$ between the attitudes of parents towards the advertised food, the behaviour related to the purchase i.e. the request to purchase such food, the conflicts with parents and the influence on the creation of unhealthy eating habits. As a result, parents believe that advertising of all unhealthy food should be prohibited (mean value 3.96), but only slightly more parents that it should also be prohibited to advertise unhealthy food to children under 12 years of age (mean value 3.99). It can be gathered from the above that the parents are not informed, nor aware of the effects that advertising may have on children in different age groups. Also, in their express opinion they believe that television should broadcast more programmes on physical exercise and a healthy nutrition (mean value 4.57), that are not featured at all in the observed time slots. The parents have clear opinions about the contents of the food adverts, and believe that they should include the nutritional value of the food (mean value 4.16), and that, in their express opinion, animated characters and celebrities should not advertise unhealthy foods (mean value 4.12), which would, however, be desirable in advertising of healthy foods (mean value 4.12). 
Table 3

Correlation analysis

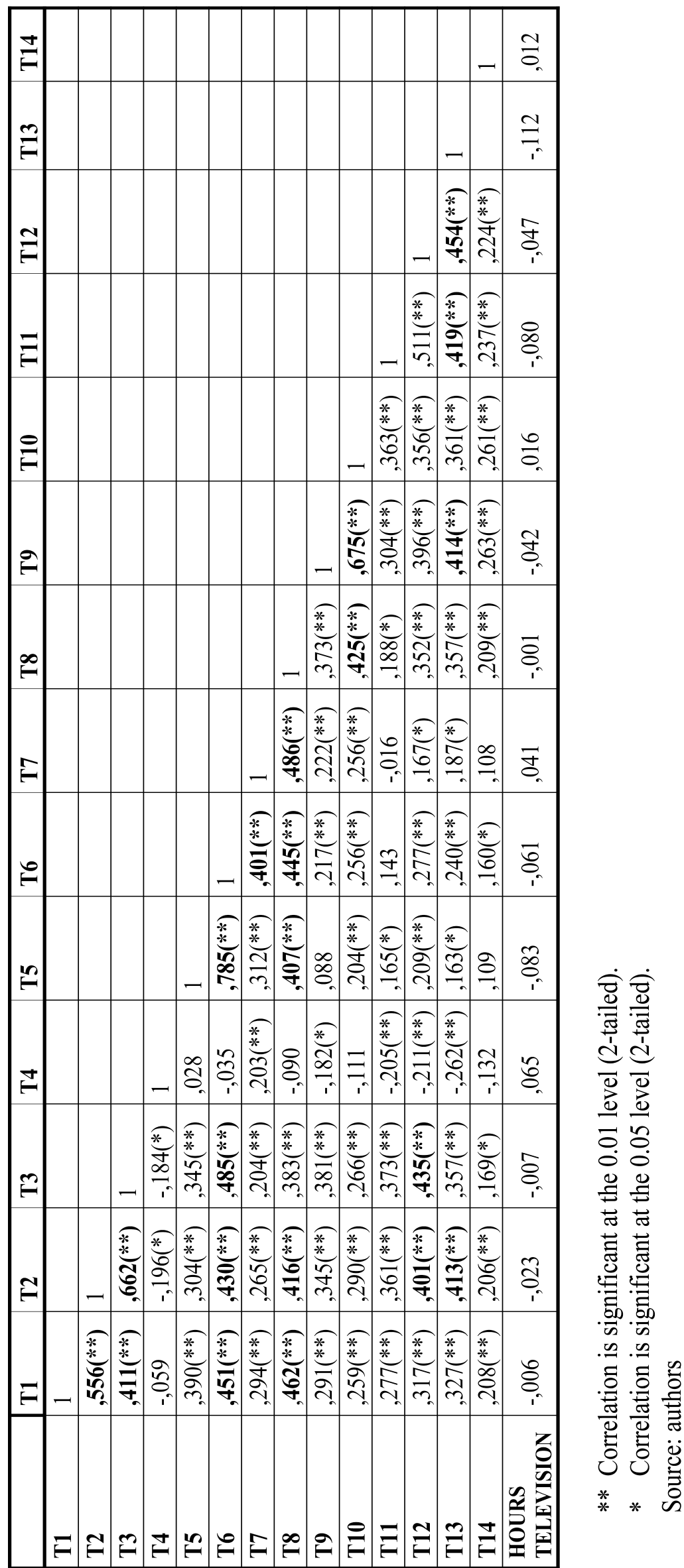




\subsubsection{RESEARCH OF THE CORRELATION BETWEEN THE ATTITUDES OF PARENTS TOWARDS ADVERTISED FOOD, THE INFLUENCE OF FOOD ADVERTISING ON CHILDREN AND THE ATTITUDES OF THE PARENTS TOWARDS THE FOOD ADVERTISING REGULATIONS}

The research tried to establish the influence of the parent's attitudes towards advertised foods and the influence of food advertising on children based on the attitudes of the parents on the necessity of regulation of food advertising. For the purpose of establishing of the correlations between the mentioned constructs the structural equations modelling (SEM) was used. SEM enables a simultaneous testing of the relationships between the constructs described with several variables. So the first exogenous latent variable (construct) is the attitude of the parents measured with tree manifest variables i.e. statements (items) T1, T2 and T3. The second exogenous latent variable - the attitude of the parents towards the influence of food advertising on children was measured with five manifest variables (T4, T5, T6, T7, T8). Finally, the endogenous latent variable - the attitude of the parents towards the legislative regulations of food advertising aimed at children was measured with six manifest variables. All manifest variables were measured with the Likert 5-degree scale where 1 stands for "I do not agree at all" and 5 stands for "I entirely agree". Manifest variables were established on the basis of the secondary researches, mentioned in the previous chapters.

The structural model intended for testing presupposes that the attitude of the parents towards the advertised food significantly and positively influences the attitude of the parents towards the regulation of food advertising to children (H2). Also, the theoretical model presupposes a significantly positive influence of the parents' attitude on the influence of food advertising on children and the attitude of the parents towards the regulation of food advertising (H3).

Before the testing of the proposed model, we tested the suppositions, as well as the suitability of the collected data for the SEM. The testing of suppositions for the SEM included: identification and elimination of the univariate and multivariate outliers, the testing of the univariate and multivariate normality of the distribution of the variables, determination of reliability of the measurement scales and the determination of the convergent and discriminant validity by use of the confirmatory factor analysis.

10 univariate outliers were therefore first excluded from the analysis. Univariate outliers are cases (observances) above and under three standard deviations from the mean value (Hair et. al; 2006; 75). In order to determine the multivariate outliers the square of Mahalanobis distance was calculated according to which none of the observances displayed a great distance with respect to all the other observances. In order to test the univariate normality of distribution of single variables the symmetry and kurtosis indexes were measured. The values of symmetry and curtosis indexes for all the analysed variables in the final model were lower than 3 . In this sense none of the variables showed an unacceptable level of univariate normality. In order to test the multivariate normality of the distribution of a group of variables the Mardia based Kappa curtosis index was calculated. The Mardia Based Kappa index for the final model equals 30,619 (C.R=12,771) and is higher than 5, which shows that there is no multivariate normality. Nevertheless, despite that, even though the disregard of the supposition of multivariate normality in SEM can lead to model parameter overestimation, a research of parallel methods of model parameter evaluation indicates that conclusions about the statistical significance of certain parameters may be accepted (Byrne, 2010).

The reliability of the scales has been established by the Cronbach alpha coefficient. Table 4 shows the Cronbach alpha coefficients for single scales (latent variables) and statements (manifest variables-indicators). 


\section{Table 4}

\section{Cronbach alpha coefficients and the influence of single statements on the Cronbach alpha coefficient of a single measuring scale}

\begin{tabular}{|c|c|}
\hline Scale - statement & $\begin{array}{l}\text { Cronbach alpha - if the statement is } \\
\text { omitted }\end{array}$ \\
\hline \multicolumn{2}{|l|}{$\begin{array}{l}\text { Cronbach alpha for the whole scale }- \\
\text { Attitude of the parents } \\
\mathbf{0 . 7 7 2}\end{array}$} \\
\hline $\mathrm{T} 1$ & 0.796 \\
\hline $\mathrm{T} 2$ & 0.578 \\
\hline T3 & 0.707 \\
\hline \multicolumn{2}{|c|}{$\begin{array}{l}\text { Cronbach alpha coefficient for the scale - } \\
\text { Attitude of the parents towards the influence that advertising has on children (SRUOD): } \\
\mathbf{0 . 6 6 8}\end{array}$} \\
\hline T4 & $\begin{array}{ll} & 0.781 \\
\end{array}$ \\
\hline T5 & 0.544 \\
\hline T6 & 0.529 \\
\hline $\mathrm{T} 7$ & 0.565 \\
\hline $\mathrm{T} 8$ & 0.662 \\
\hline \multicolumn{2}{|c|}{$\begin{array}{l}\text { Cronbach alpha coefficient for the scale - } \\
\text { Attitude of the parents towards food advertising regulations (REGULACIJA): } \\
\mathbf{0 . 7 8 0}\end{array}$} \\
\hline T9 & 0.727 \\
\hline $\mathrm{T} 10$ & 0.731 \\
\hline T11 & 0.756 \\
\hline $\mathrm{T} 12$ & 0.746 \\
\hline T13 & 0.730 \\
\hline T14 & 0,784 \\
\hline
\end{tabular}

Source: Authors' calculation

The calculated Cronbach alpha coefficients indicate at an acceptable level of reliability of the scales SROH and REGULACIJA (higher than 0.7) and an unacceptable level of reliability of the scale SRUOD (Cronbach alpha $=0.668$ ), but which can be improved to 0.781 if statement 4 is excluded from further analyses.

After the testing of the reliability of scales we tested their unidimensionality and their convergent and discriminant validity. The unidimensionality presupposes a group of manifest variables that belong to only one latent variable. The convergent validity shows the degree up to which single manifest variables - statements of a specific construct - converge, that is to say, pool a large portion in a common variance. The discriminant validity shows the degree to which one latent variable differs from others.

On the basis of a confirmatory factor analysis of the initial structural model the statements 7, 10 and 14 were excluded, in the given order. After the exclusion of each statement a confirmatory factor analysis was carried out. The statements 7 and 14 were excluded because of low standardized loadings that amounted to 0.4 (less than 0.5 ) for both statements, while statement 10 was excluded on the basis of the modification index which showed that improvements of the model are possible by lowering of the chi square value. The lowering of the chi square value after the exclusion of statement 10 resulted in 58.339. By an analysis of the contents of the statements 7, 10 and 14 it was possible to notice their similarity 
to the statements 6,9 and 13 and it was for this reason that their exclusion with the purpose of improvement of the final model was considered justified. The results of the confirmatory factor analysis for the final model are given in Table 5. The evaluation of the model parameters was done by the use of the Maximum Likelihood (ML) method.

Table 5

\begin{tabular}{|l|r|r|r|c|}
\hline $\begin{array}{c}\text { Construct - latent } \\
\text { variable, } \\
\text { statements }\end{array}$ & $\begin{array}{c}\text { Results of the confirmatory factor analysis } \\
\text { coefficients } \\
\text { (Regression } \\
\text { weights) (C.R.) }\end{array}$ & $\begin{array}{c}\text { Standardized } \\
\text { loadings }\end{array}$ & CR & AVE \\
\hline SROH & $0.933^{*}(7.281)$ & 0.619 & & $\mathbf{0 . 5 6}$ \\
\hline T1 & $1.023^{*}(9.932)$ & 0.817 & & \\
\hline T2 & 1.000 & 0.785 & & $\mathbf{0 . 8 1}$ \\
\hline T3 & 1.000 & 0.817 & & \\
\hline SRUOD & $1.214^{*}(11.811)$ & 0.954 & & \\
\hline T5 & $0.583^{*}(6.265)$ & 0.481 & & \\
\hline T6 & $0.978^{*}(5.727)$ & 0.45 \\
\hline T8 & $0.803^{*}(6.572)$ & 0.628 & & \\
\hline REGULACIJA & $1.220^{*}(7.181)$ & 0.796 & & \\
\hline T9 & 1.000 & 0.645 & & \\
\hline T11 & & & \\
\hline T12 & & & \\
\hline T13 & & & \\
\hline
\end{tabular}

*Note: structural coefficients are statistically significant $(\mathrm{p}<0,001)$

C.R. - Critical ratio, CR - Construct Reliability, AVE- Average Variance Extracted

Source: Authors' calculation

According to the data from Table 5 all structural coefficients are statistically significant, while standardised loadings are greater than 0.5 , except for statement 8 , but since the quality of the model does not significantly improve by elimination of this statement, it was preserved. The unidimensionality of the manifest variables was thus confirmed. The convergent validity was tested with the construct reliability indicator $\mathrm{CR}$ and the average variance extracted. For the entire construct the CR index is greater than 0.7 while the AVE indicator is greater or close to 0.5 . The mentioned indicators confirm the acceptable level of convergent validity of the manifest variables. The discriminant validity was established by the comparison of AVE indicators and the squared correlations between single constructs. The AVE indicators and the squared correlations between single constructs are shown in Table 6. 


\section{Table 6}

\section{Comparison between AVE indicators and squared correlations between constructs}

\begin{tabular}{|l|l|l|l|}
\hline & SROH & SRUOD & REGULACIJA \\
\hline SROH & $\mathbf{0 , 5 6}$ & & \\
\hline SRUOD & 0,38 & $\mathbf{0 , 6 0}$ & \\
\hline REGULACIJA & 0,48 & 0,12 & $\mathbf{0 , 4 5}$ \\
\hline
\end{tabular}

Source: Authors' calculation

Since all the AVE indicators are almost equal or significantly greater than single squared coefficients of correlation between single constructs it is possible to conclude that an acceptable level of discriminant validity exists. Finally, in order to establish the suitability and quality of the final SEM, we provide the FIT indexes for the structured model for the empirical data in Table 7.

Table 7

Fit indexes for the structural model

\begin{tabular}{|l|l|}
\hline Chi square/degrees of freedom & 2.356 \\
\hline Goodness-of-Fit Index (GFI) & 0.922 \\
\hline Adjusted Goodness - of - Fit Index (AGFI) & 0.866 \\
\hline Normed Fit Index (NFI) & 0.890 \\
\hline Comparative Fit Index (CFI) & 0.932 \\
\hline Incremental Fit Index (IFI) & 0.934 \\
\hline The Tucker Lewis Coefficient (TLI) & 0.902 \\
\hline
\end{tabular}

Source: Authors' calculation

The data from Table 7 indicate at the good quality of the model - the theoretical model fits appropriately to the empirical data. The relation between the chi square and the degrees of freedom is less than 2.5 while all the other indexes are greater than or close to 0.9 .

After having established that the model fits the empirical data for the testing of the hypotheses it was necessary to carry out the structural model analysis (Path analysis). Table 8 shows the results of the structural model analysis.

Table 8

Structural model analysis results

\begin{tabular}{|l|c|}
\hline HYPOTHESIS & Standardised structural coefficient \\
\hline $\mathrm{H} 2: \mathrm{SROH} \rightarrow$ REGULACIJA $(+) \mathrm{I}$ & $0.771^{*}$ \\
\hline $\mathrm{H} 3:$ SROUD $\rightarrow$ REGULACIJA $(+)$ & -0.123 \\
\hline
\end{tabular}

* Significant at level $\mathrm{p}<0,001$

Source: Authors' calculation

The attitude of the parents towards advertising has a significantly positive influence on the attitude of the parents towards regulation, thereby confirming the $\mathrm{H} 2$ hypothesis. On the other hand, the attitude of the parents towards the influence of advertising does not have a statistically significant influence on the attitude of the parents towards the regulation of food advertising on television and therefore $\mathrm{H} 3$ has been discarded. On this basis, it can be 
concluded that parents form their attitudes about regulations primarily on the basis of their personal perception of the advertising, and not as much on their perceptions of their children's behaviour. In other words, even though parents believe that advertising on television influences children's' behaviour and their tendencies to choose such foods, they form their opinion on the necessity of regulation of this issue on the basis of their own opinion about such food. The following question arises: Could it be that advertising to children on Croatian television channels and the influence of such advertising on unhealthy eating habits are still not conspicuous enough to cause a stronger reaction of the parents and to result in the awareness of the necessity for the proper legal regulation of this issue? The answer may be confirmative, but this does not justify the neglect of this issue by the legislation.

\section{CONCLUSIONS}

Advertising of food to children is one of the principal issues of the ethics in advertising. Even though a whole series of factors influences the choice of foods of a child, there is no doubt about the influence of food advertising, which eventually influences the development of nutritional habits in children. In addition to the time spent in front of the television, the influence of advertising also greatly depends on the content of the advertisement and its frequency, the type of food and the sophistication of the advertisement and its appeals, as well as the overall creative strategy and use of the possibilities of the promotional mix. The effect of food advertising on children is multiple and moderate, depending on knowledge about foods, food preferences and children's behaviour in connection with food, with recent emphasis on nutritional habits and the consequential obesity.

An important mediating role in children's consumption within socialization is played by the parents, who also have influence over food advertising to children. Their attitudes towards food advertising, in line with such researches carried out elsewhere in the world, are mostly negative, and they tend to a better regulation of this area, which involves many possibilities, ranging from the intervention into the content of the advertising to its total prohibition.

The research of parents' attitudes in Croatia does not confirm the relationship between the time spent in front of the television and the attitudes of the parents towards food advertising and their influence on the children, or the question of its legislation. Such a result may partly derive from a moderate occurrence of food advertising to children on the tracked television channels. However, the negative attitude towards the undesirable content of the advertised foods, as well as the negative influence on the nutritional habits of children has been confirmed. Therefore, the parents believe that the advertising of unhealthy food should be prohibited, but their position about the prohibition of advertising of food to children under the age of 12 is not overly restrictive. Parents have positive attitudes towards the contents of the advertising, including the emphasising of the nutritional values and the objectionability of exploitation of animated characters and celebrities, and they also believe that there should be more programmes and contents that deal with healthy nutrition. The research of the influence of the attitudes about advertising and attitudes about the knowledge and behaviour of children on the issue of adequate regulation has established that the perception of the advertising by the parents mostly influences their attitudes about the regulations, while the attitudes about knowledge and behaviour of the children do not possess a statistically significant influence. The research generally confirms the results of previous researches and indicates at the need for better legislative regulations of this issue in Croatia and a larger contribution of foods that have a positive effect on the health of children in the future. 


\section{REFERENCES}

Arnas, Y.A., (2006), «The effects of television food advertisement on children's food purchasing request», Pediatrics International, 48 (2): 138-145.

Ban, Đ., (2009), "Utjecaj ekonomske propagande na učeničku populaciju u Dubrovniku", Ekonomska misao i praksa, 18 (1):153-174.

Byrne, M.B., (2010), Structrual Equation Modeling with Amos, Routledge, New York.

Caroli, M., Argentieri, L., Cardone, M., Masi, A., (2004), «Role of television in childhood obesity prevention», International Journal of Obesity, 28: 104-108.

Chan, K., McNeal, J.U., (2003), «Parent-child communications about consumption and advertising in China», Journal of Consumer Marketing, 20 (4): 317-334.

Corbett, C., Walker, C., (2009), «Catchy cartoons, wayward websites and mobile marketing - food marketing to children in a global world», Education Review, 21 (2): 84-92.

Darwin, D., (2009), “Advertising Obesity: Can the U.S. Follow the Lead of the UK in Limiting Television Marketing of Unhealthy Foods to Children", Vanderbilt Journal of Transnational Law", 42(1): 317-350.

Dens, N., De Pelsmacker, Eagle, L., (2007), "Parental attitudes towards advertising to children and restrictive mediation of children's television viewing in Belgium", Young Consumers, 8 (1): 7-18.

Grossbart, S.L., Crosby, L.A., (1984), "Understanding the Bases of Parental Concern and Reaction to Children's Food Advertising”, Journal of Marketing, 48 (3): 79-92.

Gunter, B., Oates, C., Blades, M., (2005) Advertising to Children on TV: Content, Impact, and Regulation, Lawrence Erlbaum Associates, Inc. New Jersey.

Hair et. al., (2006), Multivariate Data Analysis, Prenitice Hall, Upper Saddle River,

Harker, D., Harker, M., Burns, R., (2007), «Tackling Obesity: Developing a Research Agenda for Advertising Researchers», Journal of Current Issues and Research in Advertising, 29 (2): 39-51..

Hastings, G., Angus, K., Caraher, M., Forsyth, A., Godfrey, C., MacKintosh, A.M., McDermott, L., Stead, M., «Review of Research on the Effects of Food promotion to Children», (2003), Final Report, University of Strathclyde, Glasgow, 22nd September: 1-218.

Hawkes, C., (2007), «Regulating Food Marketing to Young People Worlwide: Trends and Policy Drivers», American Journal of Public Health, 97 (11): 1962-1973.

Hill, H., (2002), «Packaging of children's breakfast cereal: manufactururers versus children», British Food Journal, 104 (8/9): 766-777.

Ip, J., Mehta, K.P., Coveney, J., (2007), «Exploring parent's perceptions of television food advertising directed at children: A South Australian study», Nutrition\&Dietetics, 64 (1): (50-58)

Kelly, J., Turner, J.J., McKenna, K., (2006), "What parents think: children and healthy eating", British Food Journal, 108 (5): 413-423.

Kirstin, L., (2002), «Commercialism in Schools», ERIC Digest 158:1-4. (PROVJERITI)

Lee, M., Choi, Y., Taylor Quilliam, E., Cole, R.T., (2009), «Playing With Food: Content Analysis of Food Advergames», The Journal of Consumer Affairs, 43 (1): 129-154.

Lee, W.-N., Tseng, E.S., (2006), "Food Advertising to Children: A Content Analysis Study of Television Commercials in Top Rated Tweens' Programs", American Academy of Advertising Conference Procedings, 140-149. 
Livingstone, S., (2004), «A Commentary on the Research Evidence Regarding the Effects of Food Promotion on Children», MEDIA@LSE, Department of Media and Communications, Febrary: 1-32.

Livingstone, S., (2005), «Assessing the research base for the policy debate over the effects of food advertising to children», International Journal of Advertising, 24 (3): 273-296.

Livingstone, S., Helsper, E., (2004), «Advertising Foods to Children: Understanding Promotion in The Context Of Children's Daily Lives», Report to Ofcom, London, 7th May: 29-31. http://www.ofcom.org.uk/research/tv/reportsfood ads/appendix2.pdf. (5.9.2010)

Livingstone, S., Helsper, E., (2004), «Advertising Foods to Children: Understanding Promotion in The Context Of Children's Daily Lives», MEDIACLSE, Department of Media and Communications, 7th May: 1-53.

Lobstein, T., Dibb, S., (2005), «Evidence of a possible link between obesogenic food advertising and child overweight», Obesity Reviews, 6, (3): 203-208.

Mendzigall, T., Morrison, M., (2008), "Oh Boy, Am I Hungry! An Analysis of food Advertising in Boys' Life Magazine Relative to CARU's Self-Regulatory Program for Children's Advertising", American Academy of Advertising Conference Procedings, 122-133.

Mukherji, J., (2005), «Maternal Communication Patterns, Advertising Attitudes and Mediation Behaviours in Urban India», Journal of Marketing Communications, 11 (4): 247262.

Roberts, M., Pettigrew, S., (2007) “A thematic content analysis of children's food advertising", International Journal of Advertising, 26 (3): 357-367.

Rozenkranz, R.R., Dzewaltowski, D.A., (2008), «Model of the home environment pertaning to childhood obesity», Nutrition Reviews, 66 (3): 123-140.

Schwartz, M.B., Puhl, R., (2004), «Childhood obesity: a societal problem to solve», (2003), Obesity reviews, 4 (1): 57-71.

Spungin, P. «Parent power, not pester power», (2004), Advertising \& Marketing to Children, 5 (3): 37-40.

Story, M., French, S., (2004), «Food Advertising and Marketing Directed at Children and Adolescents in the US», International Journal of Behavioral Nutrition and Physical Activity, 1: 3-17.

Walsh, A.D., Laczniak, R.N., Carlson, L., (1998), "Mothers' Preferences for Regulating Children's Television", Journal of Advertising, 27 (3): 23-36.

Wilson, N., Quigley, R., Mansoor, O., (1999), «Food ads on TV: a health hazard for children?», Australian and New Zealand Journal of Public Health, 23 (6): 647-650.

Young, B.M., de Bruin, A., Eagle, L., (2003), «Attitudes of Parents Toward Advertising to Children in the UK, Sweden and New Zealand», Journal of Marketing Management, 19 (3/4): 475-490.

Zuppa, J.A., Morton, H., Mehta, K.P., (2003), «Television food advertising: Counterproductive to children's health? A content analysis using the Australian Guide to Healthy Eating», Nutrition \& Dietetics, 6 (2): 78-84.

... (2004), »Childhood Obesity - Food Advertising in Context», Ofcom, Office of Communication, 22 July: 1-180.

... Rang lista 2008, Najoglašavanije kategorije, Lider, www.liderpress.hr $(24.9 .2010$. 


\section{PERCEPCIJE RODITELJA O OGLAŠAVANJU HRANE PREMA DJECI NA TELEVIZIJI: IZLOŽENOST, UTJECAJ I REGULATIVA}

\section{SAŽETAK}

Svrha rada je istražiti percepcije roditelja o oglašavanju hrane prema djeci na televiziji. Teorijsko istraživanje uključuje osvrt na marketing prema djeci, analizu utjecajnih čimbenika, utjecaj oglašavanja hrane prema djeci, percepcije roditelja te pitanja regulacije ovog područja oglašavanja. Empirijsko istraživanje anketnog ispitivanje percepcija roditelja ne potvrđuje vezu između vremena provedenog ispred televizora i ponašanja djece ali ukazuje na negativne stavove roditelja o oglašavanju hrane koje utječu na umjereno restriktivan stav o zabrani takvih oglasa.

Ključne riječi: oglašavanje prema djeci, televizijsko oglašavanje, percepcije roditelja, zakonska regulativa, Hrvatska 